\title{
Quantification of Temperature Fluctuations in Restaurant Coolers and Modelled Listeria monocytogenes Growth
}

\author{
Jonathan Wong ${ }^{1}$, Helen Heacock ${ }^{2}$, Vanessa Karakilic ${ }^{3}$ \\ 1 Lead Author, B. Technology Student, School of Health Sciences, British Columbia Institute of Technology, 3700 \\ Willingdon Ave, Burnaby, BC V5G 3H2 \\ 2 Supervisor, School of Health Sciences, British Columbia Institute of Technology, 3700 Willingdon Ave, Burnaby BC V5G \\ $3 \mathrm{H} 2$ \\ 3 Supervisor, School of Health Sciences, British Columbia Institute of Technology, 3700 Willingdon Ave, Burnaby BC V5G \\ $3 \mathrm{H} 2$
}

\begin{abstract}
Background: Coolers in food service establishments should ideally operate at $4{ }^{\circ} \mathrm{C}$ or less. However in restaurant environments cooler doors are continually being opened and closed as food workers gather and store items. These actions may lead to temperature fluctuations in coolers which may pose a health risk towards the storage of potentially hazardous foods. This study measured and analyzed temperature fluctuations in coolers and quantified the risk they presented by modelling Listeria monocytogenes growth in response to these temperatures.

Method: ACR Systems Inc. Smart Buttons were placed near the opening of restaurant coolers and recorded temperatures over a 1-week span. Food Spoilage and Safety Predictor (FSSP) was used to model L. monocytogenes growth in response to the collected cooler temperatures.

Results: Coolers spend significantly less than $50 \%$ of the time above $4{ }^{\circ} \mathrm{C}$. The magnitude of temperature fluctuations during open business hours was found to be insignificant in comparison to fluctuations during closed business hours. However, fluctuations were significantly greater in reach-in coolers than in walk-in coolers. With respect to modeled L. monocytogenes growth, it was inconclusive on whether growth would be more or less than Health Canada's 100cfu/g policy in smoked salmon. However growth was significantly less than this limit in ready-to-eat ham.

Conclusions: More restaurant coolers need to be analyzed to confirm whether the defrost cycles of coolers have a greater impact on temperature fluctuations above $4^{\circ} \mathrm{C}$ than the daily activities of staff members. In addition, more coolers need to be analyzed to determine whether L. monocytogenes growth in smoked salmon stored in coolers for a week grow significantly more than $100 \mathrm{cfu} / \mathrm{g}$. However, it can be concluded L. monocytogenes growth will be significantly less than $100 \mathrm{cfu} / \mathrm{g}$ in ready-to-eat ham and will pose a lower risk for listeriosis than smoked salmon.
\end{abstract}

Keywords: restaurant, coolers, temperature, fluctuation, Listeria monocytogenes, growth, smoked salmon, ready-to-eat ham. 


\section{INTRODUCTION}

This research project seeks to determine whether minor temperature fluctuations in commercial refrigeration units pose a significant health risk by promoting Listeria monocytogenes to grow to unsafe levels for human consumption. This question was originally proposed by Lorraine McIntyre of the British Columbia Centre for Disease Control as L. monocytogenes is an ongoing food safety concern due to the numerous outbreaks it has caused. The most prominent of these outbreaks are Maple Leaf Foods and their luncheon meats (1) and cantaloupes from Jensen Farms in the United States (2), which resulted in 23 and 33 deaths, respectively. Also, the most recent outbreak currently involves a grocery store in Richmond, B.C. which has resulted in at least six hospitalizations and one death (3).

Clearly, L. monocytogenes has a large impact on public health. Therefore, this review aims to explore the scientific literature to gain an understanding of the basic biological characteristics of this pathogen, where it is found in the environment, and how it can contaminate food. In addition, surveys of refrigeration temperatures will be analyzed along with studies that evaluated the growth of $L$. monocytogenes in response to a variety of temperatures on different food products. Together, these findings will depict the current knowledge status of Listeria on food safety and identify any gaps of understanding in the pathogen's nature.

\section{EVIDENCE REVIEW}

\section{Characteristics of Listeria monocytogenes and} why it is a health concern:

Listeria monocytogenes is a Gram positive, nonspore forming bacterial pathogen that has various implications that make it a serious food safety concern. Firstly, even though it is an infrequent cause of foodborne illness, it has a $20-40 \%$ mortality rate among vulnerable populations. These individuals are primarily the elderly, pregnant women and their fetuses, and other persons with weakened immune systems (4). L. monocytogenes causes the disease listeriosis where the initial symptoms include fever, muscle aches, and diarrhea (5). However, the pathogen also has the ability to cross the epithelial layer of the intestine, the blood-brain barrier, and the placental barrier which can cause life-threatening meningitis, spontaneous abortions, and stillbirths (6). As such, outbreaks of listeriosis have can have serious consequences on human life.

The second implication to consider is that $L$. monocytogenes is ubiquitous in the natural environment where it can be commonly found in soil, vegetation, water, sewage, and animal feces (7). In addition, this pathogen can also be prevalent in food processing plants and can persist on equipment for up to 12 years (4). Furthermore, the food processing workers themselves may also be a source of $L$. monocytogenes contamination where recent study has shown that $37 \%$ of workers in a cured meat plant were positive for the pathogen on their hands (8). Together, these reservoirs of $L$. monocytogenes allows for easy contamination of food products both during and after food processing.

Consequently, these food products are sold to stores and studies have attempted to measure the prevalence of contaminated foods at the retail level. However, due to the vast amount of foods that are sold every day and the relatively small sample sizes researchers were able to take, there cannot be a definitive statement on the overall presence of $L$. monocytogenes in retail foods. With regards to luncheon meats for example, Reda et al. (9) found that $5 \%$ of the meats that were surveyed contained L. monocytogenes. In contrast, Kovacevic et al. (4) found no presence of the pathogen in the deli-meats that they surveyed. With regards to seafood however, both Kovacevic et al. (4) and Gonzalez et al. (10), found that $5 \%$ of their smoked salmon samples contained L. monocytogenes.

The factor that makes the presence of $L$. monocytogenes in these foods such a concern is that these foods are ready-to-eat. This means that the foods are able to be consumed right after purchase without a cooking step in order to kill any pathogens that may be present. This is an important implication in that L. monocytogenes 
has the ability to grow at temperatures as low as $1^{\circ} \mathrm{C}(11)$ so even small amounts of $L$. monocytogenes on foods can potentially grow to hazardous levels in refrigeration units. In addition, this pathogen can grow at a wide $\mathrm{pH}$ range (4.7-9.2) and at high salt concentrations (7).

However, the exact infectious dose of $L$. monocytogenes is uncertain as it can range from 0.1 to 100 million colony forming units (11) as it may depend on the strain or L. monocytogenes and the immune status of the individual (12). Nevertheless, the number of $L$. monocytogenes that are associated with outbreaks typically range from $10^{6}-10^{8}$ colony forming units (13). Currently, Health Canada has implemented a policy in 2011 which states that ready-to-eat foods that are known to occasionally have low levels of L. monocytogenes, such as smoked salmon, (Category 2A foods) should not allow the pathogen to grow to more than $100 \mathrm{cfu} / \mathrm{g}$ (15) during its shelf life. The European Commission has taken this a step further by making this $100 \mathrm{cfu} / \mathrm{g}$ limit a regulation (14). So far, the only critical safety control for ready-to-eat foods that can suppress the growth of L. monocytogenes is maintaining strict refrigeration temperatures in order to slow the growth of L. monocytogenes so its numbers do not reach to high levels. This temperature is $4^{\circ} \mathrm{C}$ or below (16).

\section{Refrigeration temperatures:}

Even though many health inspectors and restaurant operators measure and record the temperature of refrigeration units, this data is limited in the scientific literature. However, studies have been completed on domestic refrigerators which revealed wide temperature ranges and averages that are above $4^{\circ} \mathrm{C}$. For example, Rossvoll et al. (13) found that the refrigerators they measured were between $2.9^{\circ} \mathrm{C}$ and $12.0^{\circ} \mathrm{C}$ with an average of $6.2^{\circ} \mathrm{C}$. Similarly, other studies also report means of $6^{\circ} \mathrm{C}$ (cited by $17, \mathrm{p} 2-4)$. With regards to the proportion of domestic refrigerators that are above $4^{\circ} \mathrm{C}$, numerous studies indicate that approximately $70 \%$ are operating above this level (cited by 17 , p3) and a study in Greece found that $55 \%$ of refrigerators were above $9^{\circ} \mathrm{C}$ (Sergelidis, et al, 1997). With regards to warm sections of refrigerators, there is a general trend for the top shelf to have higher temperatures but this is not true in all cases as it can sometimes be warmer on middle or bottom shelves (cited by 17, p4-5). Altogether, these non-ideal refrigeration temperatures pose a microbiological health risk in that there is a potential for L. monocytogenes to grow faster to hazardous levels in these warmer temperatures.

\section{Listeria monocytogenes-growth in response to} different temperatures:

Numerous studies have measured the growth of L. monocytogenes in response to different temperatures on various food products. Their results generally agreed with each other but also contained some differences. As expected, exposure to higher temperatures led to more rapid bacterial multiplication. With initial inoculations of $100 \mathrm{CFU} / \mathrm{g}$, one study demonstrated that it only took 3.5 days at $8^{\circ} \mathrm{C}$ for $L$. monocytogenes populations to reach outbreak levels of $10^{6} \mathrm{CFU} / \mathrm{g}$ on cold cuts, compared to 7 to 8 days at $4^{\circ} \mathrm{C}(13)$. This same growth trend was also observed in another study with ready-to-eat ham where 5 days of storage at $9^{\circ} \mathrm{C}$ led to $10^{5} \mathrm{CFU} / \mathrm{g}$. However, at $5^{\circ} \mathrm{C}$ the populations of $L$. monocytogenes were not close to those associated with outbreaks and only reached to $10^{3} \mathrm{CFU} / \mathrm{g}$, but this is still above Health Canada's limit of $100 \mathrm{cfu} / \mathrm{g}$ (18).

Similarly, this slower growth trend was also seen in fresh-cut cantaloupes where it took a week for L. monocytogenes to multiply to $10^{6} \mathrm{CFU} / \mathrm{g}$ at $8^{\circ} \mathrm{C}$ as opposed to the 3.5 days seen in cold cuts. Also, bacteria levels did not reach the $10^{6}$ CFU/g-outbreak thresholds when the cantaloupes were held at $4{ }^{\circ} \mathrm{C}$, but were above $100 \mathrm{cfu} / \mathrm{g}$ (19). This limited growth was also seen in other tropical fruits where $L$. monocytogenes could not grow at $5{ }^{\circ} \mathrm{C}$ in freshcut pitaya, mango, and papaya (20). With regards to smoked salmon however, levels of $L$. monocytogenes surpassed outbreak- associated levels at $5^{\circ} \mathrm{C}$ as the pathogen was found to grow to $10^{8} \mathrm{CFU} / \mathrm{g}$ in the absence of competitive spoilage bacteria. However, this was over a course of 193 days as opposed to a week (21). In all, these studies show that L. monocytogenes have the ability to grow at temperatures at or around $4^{\circ} \mathrm{C}$ and surpass Health Canada's 
category 2A limit depending on the food product the pathogen is growing on.

Altogether, this research is valuable in that they help predict the growth of $L$. monocytogenes at fixed temperatures over specified times. However there is a gap in these studies in that, while they measured the constant average temperature over a period of time and its effect on the growth of L. monocytogenes in a controlled environment, they did not analyze the potential of minor temperature fluctuations which may have an impact on $L$. monocytogenes' growth. In a restaurant environment there may be temperature spikes due to the opening and closing of doors in addition to routine defrost cycles that refrigerators undergo. Furthermore, the initial placement of large batches of hot foods, such as soups, into coolers may also contribute temporary increases of temperature. Therefore there is a possibility for refrigeration temperatures to be much higher than $4^{\circ} \mathrm{C}$ for short periods of time, thus potentially allowing the growth of L. monocytogenes and other pathogens to multiply faster to unsafe levels.

\section{Conclusion:}

Listeria monocytogenes is a unique pathogen as it can easily contaminate foods, can survive a wide $\mathrm{pH}$ rage, is able to live in high salt concentrations, and has the ability to grow at refrigeration temperatures. In addition, studies have shown that many refrigerators do not operate at optimal conditions which can allow for faster multiplication of L. monocytogenes to potentially hazardous levels in ready-to-eat foods. Other studies have provided evidence that support where L. monocytogenes was shown to be able to grow to outbreak-associated levels if food products are left in the fridge for a little over a week.

However, the studies relating to refrigeration temperatures were only conducted in a home environment as opposed to a busier restaurant environment and did not analyze minor temperature fluctuations that these coolers may have undergone. For example, there were no studies that specifically investigated the total time coolers spend above $4^{\circ} \mathrm{C}$ or analyzed the magnitude of these fluctuations.

Therefore, this study measured and analyzed temperature variations in refrigeration units in restaurant establishments. This was

accomplished two ways: i) determining whether the proportion of time above $4^{\circ} \mathrm{C}$ is greater or less than 0.5 and ii) comparing the area under the temperature-time curve above $4{ }^{\circ} \mathrm{C}$ and seeing whether there are any differences between when a food establishment is open or closed for business. In addition, the gathered temperature measurements were entered into a modelling program to predict the amount of $L$. monocytogenes growth there would be if the pathogen was exposed to these conditions.

\section{METHODS}

Time Span of the Study:

Three different food service establishments participated in the study and the temperatures of 10 different coolers (eight reach-in coolers \& two walk-in coolers) were logged over a 7-day span. This time span of seven days was chosen in order to obtain a representation of the "busy" and "slow" periods that food establishments experience in a typical week. This data collection occurred between January 12, 2017 and January 20, 2017.

SmartButtons in reach-in coolers: 4D 21, 4F 21, 6D 21, 60 21, 71 21, 88 21, 91 21, C0 21. SmartButtons in walk-in coolers: 70 21, EE 21.

\section{Inclusion and Exclusion Criteria:}

24-hour food establishments were excluded because a goal of the study investigates whether the intensity of temperature fluctuations above $4^{\circ} \mathrm{C}$ is greater when a food establishment is open compared to when they are closed. In addition, open display coolers were also excluded as this study explores whether the opening or closing of cooler doors has an impact on temperatures.

\section{Setup and Placement of SmartButtons:}

Since each SmartButton only has enough memory for 2,048 consecutive temperature measurements (22), measuring at time intervals that are less than five minutes would have resulted in the SmartButtons' memory being 
filled before the 7-day period was complete. Therefore, each SmartButton was programmed to record temperatures every five minutes.

In addition each SmartButton was placed near the opening of each cooler. The rationale for this is that areas near the opening would experience most of the temperature fluctuations due to restaurant workers opening cooler doors to grab food products (23). To ensure that the SmartButtons did not become lost, each device was placed in a small mesh pouch and tied to a shelf post or the shelf's wiring. A mesh material was chosen to ensure that the SmartButtons would receive adequate airflow for proper temperature recording.

\section{Calibration of SmartButtons:}

Each SmartButton was set to record temperatures at 1-minute intervals. At the beginning of each time interval, a calibrated Traceable ${ }^{\circledR}$ Ultra Waterproof Food

Thermometer was used to record the current air temperature. The collected SmartButton temperatures were then compared to the temperatures recorded from the probe thermometer and any discrepancies were noted and corrected for after the data was imported into Microsoft Excel for analysis.

Determining the Proportion of Time Spent Above $4^{\circ} \mathrm{C} \&$ the Area Under the Curve Above $4^{\circ} \mathrm{C}$ :

The drafting program, AutoCAD was used to determine these values (24).

\section{Modelling Listeria monocytogenes growth in FSSP:}

Within FSSP, the model "Listeria monocytogenes in chilled seafood and meat products" was chosen and the subcategory, "Growth of L. monocytogenes: Effect of temp., atmosphere, salt, smoke, $\mathrm{pH}$, nitrite and organic acids" was chosen. To simulate food products contaminated with $L$. monocytogenes, the program parameters were adjusted to mimic smoked salmon and ready-to-eat ham. These parameters were set as follows:

\begin{tabular}{|c|c|c|}
\hline $\begin{array}{c}\text { L. } \\
\text { monocytogenes } \\
\text { initial cell level } \\
\text { (cfu/g) }\end{array}$ & Smoked Salmon & $\begin{array}{c}\text { RTE } \\
\text { Ham }\end{array}$ \\
\hline $\begin{array}{c}\text { NaCl in water } \\
\text { phase \% }\end{array}$ & $10 \mathrm{cfu} / \mathrm{g}$ & $\begin{array}{c}10 \\
\mathrm{cfu} / \mathrm{g}\end{array}$ \\
\hline pH & $\begin{array}{l}3.5 \\
(0.98\end{array}$ & $\begin{array}{c}7.0 \\
(0.96 \\
\left.\mathrm{A}_{\mathrm{w}}\right)\end{array}$ \\
\hline $\begin{array}{c}\text { Smoke } \\
\text { components - } \\
\text { phenol (ppm) }\end{array}$ & 6.2 & 6.7 \\
\hline $\begin{array}{c}\text { \% CO } \mathbf{\text { in }} \\
\text { headspace gas } \\
\text { at equilibrium }\end{array}$ & 0 & 0 \\
\hline Nitrite, mg/kg & 0 & 0 \\
\hline
\end{tabular}

For both food products, the initial cell contamination was chosen to be $10 \mathrm{cfu} / \mathrm{g}$. This was based on studies by Beaufort et al.(25) and Gonzalez et al.(10) which found that retail ready-to-eat products contaminated with $L$. monocytogenes typically had less than $10 \mathrm{cfu} / \mathrm{g}$. With regards to smoked salmon, the values for percentage of $\mathrm{NaCl}$ and $\mathrm{pH}$ are characteristic of smoked salmon products (26). With respect to the ready-to-eat ham, the $\mathrm{NaCl}$ percentage in water/water activity and $\mathrm{pH}$ were based on values found by Garrido et al. (18). Finally, for the final three parameters, a zero value was assigned for simplicity as discussed with Ms. McIntyre, Mr. Shyng, and Mr. Barrios (27).

With regards to the input of data into FSSP, the program only accepts time intervals in hours so the raw times collected by the SmartButtons were converted to hours from minutes in Excel.

\section{ETHICAL CONSIDERATIONS}

All food establishments that participated in the study were and will be kept anonymous.

\section{RESULUTS}

Microsoft Excel 2007 was used to gather descriptive statistics and NCSS 11 was used to 
conduct one-sample t-tests and two-sample ttests. The statistical analysis was done on the three parts of the project:
i)
Analysis of the total time the
ii) Analysis of the total area/hr. above $4^{\circ} \mathrm{C}$ between open and closed business hours of all coolers.
iii) Analysis of L. monocytogenes growth in simulated smoked salmon and ready-to-eat ham.

\section{1) Analysis of the Proportion of Time Spent Above $4^{\circ} \mathrm{C}$ :}

It was investigated whether coolers spend more than half the time above $4^{\circ} \mathrm{C}$. This was accomplished by comparing the proportion of time each cooler was above $4^{\circ} \mathrm{C}$ during 7 days to 0.5 . Two analyses were conducted:

i) Proportion of time above $4^{\circ} \mathrm{C}$ during open business hours.

ii) Proportion of time above $4^{\circ} \mathrm{C}$ during closed business hours.

\section{Inferential Statistics:}

A one-sample $t$ test was conducted. The standard that the numerical data was compared to was 0.5 .

\section{Interpretation:}

i) Open Hours

\begin{tabular}{|l|l|}
\hline $\mathbf{H}_{\mathbf{O}}:$ & $\begin{array}{l}\text { The proportion of time spent } \\
\text { above } 4^{\circ} \mathrm{C} \text { is greater than or } \\
\text { equal to } 0.5 \text { during open hours. }\end{array}$ \\
\hline $\mathbf{H}_{\mathbf{a}}:$ & $\begin{array}{l}\text { The proportion of time spent } \\
\text { above } 4^{\circ} \mathrm{C} \text { is less than } 0.5 \\
\text { during open hours. }\end{array}$ \\
\hline Test Used: & Wilcoxon Signed-Rank Test \\
\hline Result: & $\mathrm{P}=0.0372$; Power $=0.804$ \\
\hline Conclusion: & $\begin{array}{l}\text { Reject } \mathrm{H}_{\mathrm{O}} \text { and conclude that } \\
\text { coolers spend less than half the } \\
\text { time above } 4{ }^{\circ} \mathrm{C} \text {. Power is } \\
\text { greater than } 0.80 \text { indicating it } \\
\text { is a powerful study. Since } \mathrm{P}> \\
0.01, \text { there is a potential } \alpha \\
\text { error. }\end{array}$ \\
\hline
\end{tabular}

ii) Closed Hours

\begin{tabular}{|l|l|}
\hline Ho: & $\begin{array}{l}\text { The proportion of time spent } \\
\text { above } 4^{\circ} \mathrm{C} \text { is greater than or }\end{array}$ \\
\hline
\end{tabular}

\begin{tabular}{|l|l|}
\hline & $\begin{array}{l}\text { equal to } 0.5 \text { during closed } \\
\text { hours. }\end{array}$ \\
\hline $\mathbf{H}_{\mathbf{a}}:$ & $\begin{array}{l}\text { The proportion of time spent } \\
\text { above } 4^{\circ} \mathrm{C} \text { is less than } 0.5 \\
\text { during open hours. }\end{array}$ \\
\hline Test Used: & Wilcoxon Signed-Rank Test \\
\hline Result: & $\mathrm{P}=0.0293$; Power $=0.840$ \\
\hline Conclusion: & $\begin{array}{l}\text { Reject } \mathrm{H}_{\mathrm{O}} \text { and conclude that } \\
\text { coolers spend less than half the } \\
\text { time above } 4^{\circ} \mathrm{C} \text {. Power is } \\
\text { greater than } 0.80 \text { indicating it } \\
\text { is a powerful study. Since } \mathrm{P}> \\
0.01, \text { there is a potential } \alpha \\
\text { error. }\end{array}$ \\
\hline
\end{tabular}

\section{2) Analysis of Area/hr. above $4^{\circ} \mathrm{C}$ between Open Business Hours vs. Closed Business Hours:}

In addition to determining the amount of time spent above $4^{\circ} \mathrm{C}$, another goal of the study was to quantify the magnitude the temperatures rose above $4^{\circ} \mathrm{C}$ during a one-week span. To do this, the area under the curve above $4^{\circ} \mathrm{C}$ was calculated. Here, comparisons of areas of when food establishments were open or closed for business were performed. Since different food establishments have different operating hours, the areas under the curve were converted to unitarea/hour-open $\left({ }^{\circ} \mathrm{C}^{*}\right.$ minute/hour $)$ and unitarea/hour-closed $\left({ }^{\circ} \mathrm{C}^{*}\right.$ minute/hour) so comparisons between different restaurants could be conducted. Three different analyses were conducted:

i) Comparison of areas $/ \mathrm{hr}$. between open and closed business hours for all ten coolers.

ii) Comparison of areas $/ \mathrm{hr}$. between open and closed business hours for reach-in coolers.

iii) Comparison of areas $/ \mathrm{hr}$. between open and closed business hours for walk-in coolers.

\section{Inferential Statistics:}

Two-sample t-tests were conducted on the continuous numerical data for each of the three analyses.

\section{Interpretation:}




\begin{tabular}{|c|c|}
\hline $\mathbf{H}_{0}:$ & $\begin{array}{l}\text { The area/hr. above } 4^{\circ} \mathrm{C} \text { during } \\
\text { open business hours is less } \\
\text { than or equal to the area/hr. } \\
\text { when the business is closed. }\end{array}$ \\
\hline $\mathbf{H}_{\mathrm{a}}:$ & $\begin{array}{l}\text { The area/hr. above } 4^{\circ} \mathrm{C} \text { during } \\
\text { open business hours is greater } \\
\text { than the area/hr. when the } \\
\text { business is closed. }\end{array}$ \\
\hline Test Used: & $\begin{array}{l}\text { Mann-Whitney U or Wilcoxon } \\
\text { Rank-Sum Test }\end{array}$ \\
\hline Result: & $\begin{array}{l}\text { All Coolers: } \mathrm{P}=0.0993 ; \\
\text { Power }=0.0714 \\
\text { Only Reach }- \text { In Coolers: } \mathrm{P}= \\
0.147 ; \text { Power }=0.0710 \\
\text { Only Walk }- \text { In Coolers: } \mathrm{P}= \\
0.0512 ; \text { Power }=0.190\end{array}$ \\
\hline Conclusion: & $\begin{array}{l}\text { All Coolers: Cannot reject } \mathrm{H}_{\mathrm{O}} \\
\text { and cannot conclude that the } \\
\text { area/hr. above } 4^{\circ} \mathrm{C} \text { was greater } \\
\text { when restaurants were open } \\
\text { for businesses than closed. P- } \\
\text { value is close to } 0.05 \text { and } \\
\text { power is less than } 0.80 \text { so } \\
\text { there is a potential } \beta \text {-error. } \\
\text { More coolers need to be } \\
\text { sampled. } \\
\text { Only Reach - In Coolers: } \\
\text { Cannot reject Ho and cannot } \\
\text { conclude that the area/hr. } \\
\text { above } 4{ }^{\circ} \mathrm{C} \text { was greater during } \\
\text { open business hours than } \\
\text { closed hours for reach-in } \\
\text { coolers. } \\
\text { Power is less than } 0.80 \text { so } \\
\text { more reach-in coolers need to } \\
\text { be sampled to increase the } \\
\text { power of the study. } \\
\text { Only Walk - In Coolers: } \\
\text { Cannot reject Ho and cannot } \\
\text { conclude that the area/hr. } \\
\text { above } 4{ }^{\circ} \mathrm{C} \text { was greater when } \\
\text { restaurants were open for } \\
\text { businesses than closed. P- } \\
\text { value is close to } 0.05 \text { and } \\
\text { power is less than } 0.80 \text { so } \\
\text { there is a potential } \beta \text {-error. } \\
\text { More coolers need to be } \\
\text { sampled. }\end{array}$ \\
\hline
\end{tabular}

\section{3) Analysis of Area/hr. above $4^{\circ} \mathrm{C}$ between Reach-in Coolers vs Walk-in Coolers During Open \& Closed Business Hours:}

The above statistical interpretations indicated that that area/hr. above $4{ }^{\circ} \mathrm{C}$ was insignificant between a restaurant's open and closed business hours. However, considering that the p-value for the walk-in coolers was very close to the 0.05 threshold of significance, there is possibility of a beta-error. Therefore, it was investigated whether reach-in coolers experienced more fluctuations for both open and closed business hours than walk-in coolers.

\section{Inferential Statistics:}

A two-sample t-test was conducted on the continuous numerical data.

Interpretation:

\begin{tabular}{|l|l|}
\hline $\mathbf{H}_{\mathbf{O}}:$ & $\begin{array}{l}\text { The area/hr. above } 4^{\circ} \mathrm{C} \text { in } \\
\text { reach-in coolers is less than or } \\
\text { equal to the area/hr. above } 4^{\circ} \mathrm{C} \\
\text { in walk-in coolers. }\end{array}$ \\
\hline $\mathbf{H}_{\mathbf{a}}$ : & $\begin{array}{l}\text { The area/hr. above } 4^{\circ} \mathrm{C} \text { in } \\
\text { reach-in coolers is greater than } \\
\text { the area/hr. above } 4^{\circ} \mathrm{C} \text { in } \\
\text { walk-in coolers. }\end{array}$ \\
\hline Test Used: & $\begin{array}{l}\text { Mann-Whitney U or Wilcoxon } \\
\text { Rank-Sum Test }\end{array}$ \\
\hline Result: & $\begin{array}{l}\text { During Open Business } \\
\text { Hours: } \mathrm{P}=0.0184 ; \text { Power }= \\
0.483 \\
\text { During Closed Business } \\
\text { Hours: } \mathrm{P}=0.0181 ; \text { Power }= \\
0.345\end{array}$ \\
\hline Conclusion: & $\begin{array}{l}\text { During Open Business } \\
\text { Hours: Reject } \mathrm{H}_{\mathrm{O}} \text { and } \\
\text { conclude that the area/hr. } \\
\text { above } 4{ }^{\circ} \mathrm{C} \text { was greater in } \\
\text { reach-in coolers than in walk- } \\
\text { in coolers during open } \\
\text { business hours. } \\
\text { Power is less than } 0.80 \text { so } \\
\text { more coolers need to be } \\
\text { sampled. Since } \mathrm{P}>0.01, \text { there } \\
\text { is potential for } \alpha-\text { error. } \\
\text { During Closed Business } \\
\text { Hours: Reject } \mathrm{H}_{\mathrm{O}} \text { and } \\
\text { conclude that the area/hr. }\end{array}$ \\
\hline
\end{tabular}




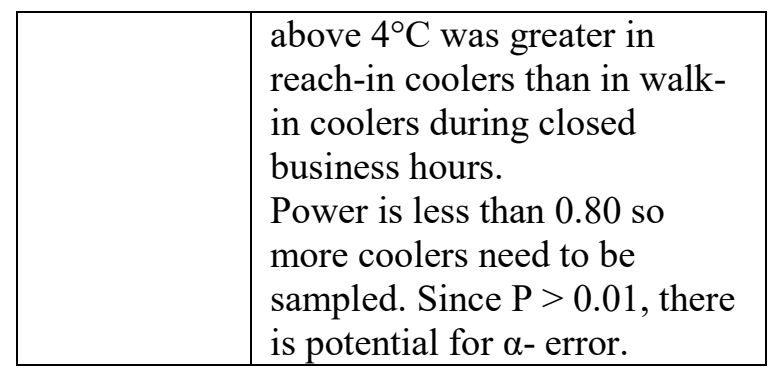

\section{4) Analysis of L. monocytogenes growth in smoked salmon and ready-to-eat ham:}

In this study, having L. monocytogene growth exceeding $100 \mathrm{cfu} / \mathrm{g}$ was labelled as a health risk. This is based on the policy implemented by Health Canada in 2011 which stated that readyto-eat foods that are known to occasionally have low levels of L. monocytogenes (Category 2A foods) should not have L. monocytogenes growth greater than $100 \mathrm{cfu} / \mathrm{g}$ during the prescribed shelf life (28). To model $L$. monocytogenes growth over 7 days, Food Spoilage and Safety Predictor (FSSP), was used to determine the total growth of the pathogen if it was subjected to the temperatures gathered from the SmartButtons.

\section{Inferential Statistics:}

A one-sample t-test was conducted for both $L$. monocytogenes growth on smoked salmon and ready-to-eat ham with $100 \mathrm{cfu} / \mathrm{g}$ being the comparison standard.

\section{Interpretation:}

\begin{tabular}{|l|l|}
\hline Ho: & $\begin{array}{l}\text { The growth of L. monocytogenes } \\
\text { is equal to or exceeds 100cfu/g. }\end{array}$ \\
\hline $\mathbf{H}_{\mathbf{a}}:$ & $\begin{array}{l}\text { The growth of } L . \text { monocytgoes is } \\
\text { less than } 100 \mathrm{cfu} / \mathrm{g} .\end{array}$ \\
\hline Test Used: & $\begin{array}{l}\text { Wilcoxon Rank-Sum Test; One } \\
\text { Sample T Test (for Walk-in } \\
\text { Coolers Only) }\end{array}$ \\
\hline Result: & $\begin{array}{l}\text { Smoked Salmon in All Coolers: } \\
\mathrm{P}=0.207 ; \text { Power }=0.00820 \\
\text { Smoked Salmon in Only Reach- } \\
\text { In Coolers: } \mathrm{P}=0.444 ; \text { Power }= \\
0.00678\end{array}$ \\
\hline
\end{tabular}

\begin{tabular}{|l|l|}
\hline Smoked Salmon in Only Walk- \\
In Coolers: $\mathrm{P}=0.0197$; Power $=$ \\
0.992 \\
Ready-to-Eat Ham in All \\
Coolers: $\mathrm{P}=0.0415 ;$ Power $=$ \\
0.723 \\
Ready-to-Eat Ham in Only \\
Reach-In Coolers: $\mathrm{P}=0.0805 ;$ \\
Power $=0.444$ \\
Ready-to-Eat Ham in Only \\
Walk-In Coolers: $\mathrm{P}=0.00582 ;$ \\
Power $=1.00$
\end{tabular}




\begin{tabular}{|l|l|}
\hline & $\begin{array}{l}\text { L. monocytogenes growth. P }> \\
0.01 \text { so there's potential for } \alpha \\
\text { error. } \\
\text { Ready-to-Eat Ham in Only } \\
\text { Reach-In Coolers: Cannot reject } \\
\text { Ho and cannot conclude that the } \\
\text { growth of L. monocytogenes will } \\
\text { be significantly less in ready-to- } \\
\text { eat ham. P-value is close to 0.05 } \\
\text { and power is less than 0.80 so } \\
\text { there is a potential ß-error. More } \\
\text { coolers need to be sampled. } \\
\text { Ready-to-Eat Ham in Only } \\
\text { Walk-In Coolers: Reject Ho and } \\
\text { conclude that } L . \text { monocytogenes } \\
\text { growth would be significantly less } \\
\text { than } 100 \text { cfu/g if ready-to-eat ham } \\
\text { were stored in walk-in coolers for } \\
\text { a week. } \\
\text { Power is greater than } 0.80 \\
\text { meaning that the data is powerful. }\end{array}$ \\
\hline
\end{tabular}

\section{DISCUSSION}

This report sought to investigate three aspects of temperature fluctuations in restaurant coolers:

i) Whether coolers spend more than $50 \%$ of the time above $4^{\circ} \mathrm{C}$.

ii) The total magnitude of temperature fluctuations above $4^{\circ} \mathrm{C}$ by determining the area underneath the timetemperature curve.

iii) Predicting the amount of $L$. monocytogenes growth in response to the collected temperatures.

With regards to the proportion of time spent above $4^{\circ} \mathrm{C}$, it was found that restaurant coolers spent significantly less than half the time above this threshold. This was true for both open and closed business hours where p-values were 0.0372 and 0.0293 , respectively. Considering that these values are greater than 0.01 , there is the possibility of an $\alpha$-error. This possibility can be attributed to the variability of the collected data where some of the coolers, such as 7021 , operated almost exclusively below $4^{\circ} \mathrm{C}$ while other coolers fluctuated above $4^{\circ} \mathrm{C}$ more often. In fact, coolers 6D 21 and 8821 were operating at temperatures above $4^{\circ} \mathrm{C}$ for most of the week.
With respect the areas underneath the $4^{\circ} \mathrm{C}$ curve, it was found that the magnitude of temperature fluctuations during open business hours were insignificant from closed business hours ( $p=$ 0.0993). These insignificancies were also found when reach-in coolers and walk-in coolers were analyzed separately from each other $(\mathrm{p}=0.147$ and $\mathrm{p}=0.0512$, respectively). These results indicate that the defrost cycles of coolers contribute more to temperature fluctuations above $4^{\circ} \mathrm{C}$ than restaurant activities such as the opening and closing of cooler doors during business hours. If the latter were true, then the areas underneath the curves above $4^{\circ} \mathrm{C}$ would have been greater during open hours, but this is not the case. However, considering that the powers of these statistical tests were much less than 0.80 , it is very possible that the resulting insignificancies were due to the high variability of the small sample size. As mentioned above, some coolers, specifically walk-in coolers, underwent almost no temperature fluctuations above $4^{\circ} \mathrm{C}$ while some reach-in coolers experienced more spikes in temperature. Therefore, a larger sample size would need to be collected in order to differentiate fluctuations due to defrost cycles and a restaurant's daily activities.

Nevertheless, when comparing the areas of reach-in coolers versus walk-in coolers, it was concluded that reach-in coolers significantly undergo more temperature fluctuations than walk-in coolers for both open and closed business hours $(p=0.0184$ and $p=0.0181)$. This could be due to a number of reasons. Firstly, considering that there is a high potential for an $\alpha$-error, it is possible that the greater amount of fluctuations in reach-in coolers during open hours could have been due to the fact that these coolers tend to be opened and closed much more often than walk-in coolers as restaurant staff take and put away ingredients during their daily routines. Walk-in coolers on the other hand are primarily used for long-term storage, and are usually only opened when receiving shipments of supplies or taking out bulk items. This was reflected in cooler EE 21 where single, prominent spikes in temperature were seen on Jan. $13^{\text {th }}, 16^{\text {th }}, 17^{\text {th }}$, and $18^{\text {th }}$. This is confirmed by this particular restaurant operator when they 
said that they receive shipments almost daily. With regards to the second walk-in cooler (70 21 ), a spike in temperature was seen on Jan. $17^{\text {th }}$ when they received their shipments. Another contributing factor was that the walk-in coolers were normally operating at much lower temperatures $\left(\sim 0-2.5^{\circ} \mathrm{C}\right)$ compared to the reachin coolers which were operating closer to $4^{\circ} \mathrm{C}$. This could be due to the walk-in coolers' much larger volume which allows these units to maintain colder temperatures for longer periods of time. By operating at a slightly colder temperature, this would create a temperature buffer which would lessen temperature fluctuations as cooler doors open and close during business hours and during daily defrost cycles. It is also important to note that neither walk-in cooler had plastic strip curtains at their entrances meaning that walk-in coolers that do contain them may experience even less temperature fluctuations during open restaurant hours.

In addition, it was noticed that the reach-in coolers had more of their volumes filled more with food products while the walk-in coolers had more air space. This would probably impact a reach-in cooler's ability to keep colder temperatures, as revealed in cooler 6021 for example. This reach-in cooler held multiple large bins of warm pinto and black beans, which were made daily, in a relatively small space. This alludes to another point on whether cold or hot foods stored in a cooler have an effect. For example, cooler 9121 , which belongs to the same restaurant as cooler 6021 , was only filled with cold products such as pre-made BBQ sauces, fresh vegetables, and cheese and experienced less temperature fluctuations and maintained an overall colder temperature than cooler 6021.

However, how often a cooler is open and closed and the types of foods that are stored in reach-in coolers are not the sole contributors to the overall temperature of reach-in coolers. It also depends how well the coolers are operating or the correct temperature restaurant operators set their coolers at. For example, coolers 6D 21 and 8821 were reach-in coolers which mainly held colder products and still experienced a vast majority of their temperatures above $4^{\circ} \mathrm{C}$, even at night when the restaurant was closed for business.

With regards to the modelled $L$. monocytogenes growth in response to the recorded cooler temperatures, it was inconclusive on whether this growth would be greater than or less than Health Canada's policy of $100 \mathrm{cfu} / \mathrm{g}$ in smoked salmon, indicating that more coolers need to be analyzed. However, L. monocytogenes growth is significantly less than $100 \mathrm{cfu} / \mathrm{g}$ in ready-to-eat ham due to the ham's lower water activity. Also, the reach-in coolers had more L. monocytogenes growth compared to the walk-in coolers due to their greater fluctuations in temperature.

When compared to a previous study, Garrido et al. (18) found that an initial inoculum of $\sim 1$ $\mathrm{cfu} / \mathrm{g}$ on ready-to-eat ham reached to $1000 \mathrm{cfu} / \mathrm{g}$ at $5^{\circ} \mathrm{C}$ at the end of 5 days. This is much higher than the maximum $229 \mathrm{cfu} / \mathrm{g}$ in simulated readyto-eat ham found in this study. This could be attributed to the fact that Garrido et al. (18) ensured a relatively constant $5^{\circ} \mathrm{C}$ temperature in their experimental refrigerator while most of the coolers in this study were found to be operating below $4{ }^{\circ} \mathrm{C}$ for less than fifty percent of the time (i.e. an average of $80 \%$ of time below $4^{\circ} \mathrm{C}$ ) which would slow L. monocytogenes growth.

It is important to note that the parameters that were used to model L. monocytogenes growth in this study were set at ideal growth conditions to represent a worse-case scenario. For instance, competitive bacteria were not included in the simulation and nor were smoke components (i.e. phenol) and nitrites. In addition, the lag time for L. monocytogenes was also excluded in the simulation. Altogether, these aspects would have further inhibited L. monocytogenes growth in addition to colder temperatures. Therefore, there would be less growth in typical smoked salmon and ready-to-eat ham than seen in this study after one week, presenting an even lower risk for listeriosis.

\section{LIMITATIONS}

A limitation of the study was the small number of coolers that were monitored. There was a lot 
of variability in the data, especially in the reachin coolers. Differences in temperature fluctuations can be attributed to how often the coolers were used, what sort of items they stored, how full they were, and how well the coolers operated which were not controlled for. Therefore, in order to obtain a better representation of temperature fluctuations in reach-in coolers, more coolers need to be surveyed. In addition, only two walk-in coolers were analyzed. However, considering that walkin coolers typically experience less opening and closing of doors and that many walk-in coolers contain plastic strip curtains, the collected temperature fluctuation data on walk-in coolers can be seen as representative for walk-in coolers as a whole.

In addition to the limited number of coolers that were analyzed, another limitation of the project was that the SmartButtons were set to take temperatures every 5 minutes. Therefore, there may have been temperature fluctuations above or below $4^{\circ} \mathrm{C}$ within the 5 minute intervals that would not have been detected by the SmartButtons. In addition, the L. monocytogenes modelling program, FSSP, assumed that the inputted temperatures were constant for those 5 minutes which may have led to an over- or underestimate of L. monocytogenes growth.

Another constraint the study presents is that changes in air temperature do not necessarily reflect temperature changes in stored food products. It may take prolonged periods of time for air temperatures to change the surface temperature of food products, meaning that brief temperature fluctuations may not have an effect. Therefore, in order to measure any discrepancies between air and food temperatures, a simultaneous comparison should be performed between SmartButtons that are exposed to the air and those that are inserted into food items.

\section{KNOWLEDGE TRANSLATION}

To prevent exposing foods to temperature fluctuations throughout the day, food products should be placed away from doorways and closer to the back of coolers. Also, since temperature fluctuations are more likely to occur in reach-in coolers, foods that will be stored for long periods of time should be placed in walk-in coolers. Furthermore, installation of plastic strip curtains will help keep temperatures constant in walk-in coolers. Finally, restaurant operators should set their coolers to temperatures to below $4^{\circ} \mathrm{C}$ in order to create a temperature buffer to lessen fluctuations as cooler doors are being opened and closed and increases in temperature during defrost cycles.

\section{FURTURE RESEARCH}

- Determine the extent of air temperature fluctuations' effects on the temperature of food products.

- Measure more walk-in coolers and determine whether they actually do experience less temperature fluctuations.

- Conduct a controlled experiment to determine how long cooler doors need to be opened for in order to change the air temperature of coolers.

\section{CONCLUSION}

This study concluded that there were no significant differences in temperature fluctuations between open and closed business hours. This may indicate that the defrost cycles of coolers have a greater impact on temperature fluctuations above $4^{\circ} \mathrm{C}$ than the daily activities of a restaurant. However, only a small sample size of coolers was analyzed and the statistical power of these tests were much less than 0.80 so future research with more coolers should be conducted to fully confirm whether the daily operations of a restaurant do not have a significant impact on temperature fluctuations. When comparing reach-in coolers with walk-in coolers however, it was found that reach-in coolers experience greater temperature spikes above $4^{\circ} \mathrm{C}$. This is most likely due to their smaller volumes of space which makes reach-in coolers less resistant to temperature spikes. In order to minimize temperature fluctuations, operators should place food away from cooler 
entrances, install plastic strip curtains, and adjust cooler temperatures to below $4^{\circ} \mathrm{C}$ to minimize the effects of defrost cycles. Finally, the storage of smoked salmon presents a greater health risk when stored for 7 days while ready-to-eat ham presents a very low health risk for listeriosis.

\section{ACKNOWLEDGEMENTS}

This research was completed with the support of Helen Heacock, Vanessa Karakilic, and Fred Shaw of BCIT and Lorraine McIntyre, Sion Shyng, and Pablo Romero Barrios of the BCCDC. Special thanks to Daniel Wong for his instruction on how to use AutoCAD.

\section{COMPETING INTEREST}

The authors declare that they have no competing interests.

\section{REFERENCES}

(1) Foodborne Illness Outbreak Database [Internet]. [Place Unknown]: Marler Clark; [date unknown] [cited 2016 Oct 15]. Available from: http://outbreakdatabase.com/details/maple -leaf-consumer-foods-of-canada-delimeat-canada2008/?organism=Listeria + monocytogenes

(2) Centers for Disease Control and Prevention [Internet]. Atlanta: Centers for Disease Control and Prevention; 2012

Aug 27 [2012 Aug 27; cited 2016 Oct 15]. Available from:

http://www.cdc.gov/listeria/outbreaks/cant aloupes-jensen-farms/

(3) Global News [Internet]. [Place Unknown]: Corus Entertainment Inc. Corus News; 2016 Oct 14 [2016 Oct 17; cited 2016 Oct 15]. Available from http://globalnews.ca/news/3004589/sixpeople-hospitalized-following-listeriaoutbreak-at-richmond-grocery-store/

(4) Kovačević J, Mesak LR, Allen KJ. Occurrence and characterization of Listeria spp. in ready-to-eat retail foods from Vancouver, British Columbia. Food Microbiol. 2012;30(2):372-8.
(5) Centers for Disease Control and Prevention [Internet]. Atlanta: Centers for Disease Control and Prevention; 2012 Feb 27 [2014 Nov 20; cited 2016 Oct 17]. Available from https://www.cdc.gov/listeria/definition.ht $\mathrm{ml}$

(6) Jordan K, Leong D, Álvarez Ordóñez A. Listeria monocytogenes in the Food Processing Environment [Internet]. Vol. 59, Food Technology. 2015. 36-42 p.

Available from: http://link.springer.com/10.1007/978-3319-16286-7

(7) Ferreira V, Wiedmann M, Teixeira P, Stasiewicz MJ. Listeria monocytogenes Persistence in Food-Associated Environments: Epidemiology, Strain Characteristics, and Implications for Public Health. J Food Prot [Internet]. 2014;77(1):150-70. Available from: http://www.ncbi.nlm.nih.gov/pubmed/244 06014\%5Cnhttp://www.ingentaconnect.co $\mathrm{m} /$ content/iafp/jfp/2014/00000077/000000 01/art00023

(8) Saludes M, Troncoso M, Figueroa G. Presence of Listeria monocytogenes in Chilean food matrices. Food Control [Internet]. Elsevier Ltd; 2015;50:331-5. Available from:

http://www.sciencedirect.com/science/arti cle/pii/S0956713514004575

(9) Reda WW, Abdel-Moein K, Hegazi A, Mohamed Y, Abdel-Razik K. Listeria monocytogenes: An emerging food-borne pathogen and its public health implications. J Infect Dev Ctries. 2016;10(2):149-54.

(10) González D, Vitas AI, Díez-Leturia M, García-Jalón I. Listeria monocytogenes and ready-to-eat seafood in Spain: Study of prevalence and temperatures at retail. Food Microbiol [Internet]. Elsevier Ltd; 2013;36(2):374-8. Available from: http://dx.doi.org/10.1016/j.fm.2013.06.02 3

(11) Public Health Agency of Canada [Internet]. [Place unknown]: Public Health Agency of Canada; 2012 Apr 30 [cited 2016 Oct 20]. Available from: http://www.phac-aspc.gc.ca/lab- 
bio/res/psds-ftss/listeria-monocytogeneseng.php

(12) U.S. Food \& Drug Administration [Internet]. Silver Spring: U.S. Food and Drug Administration; [date unknown] [2014 Dec 16; cited 2016 Oct 20]. Available from:

http://www.fda.gov/Food/FoodborneIllnes sContaminants/CausesOffllnessBadBugB ook/ucm070064.htm

(13) Røssvoll E, Rønning HT, Granum PE, Møretrø T, Hjerpekjøn MR, Langsrud S. Toxin production and growth of pathogens subjected to temperature fluctuations simulating consumer handling of cold cuts. Int J Food Microbiol [Internet]. Elsevier B.V.; 2014;185:82-92. Available from:

http://dx.doi.org/10.1016/j.ijfoodmicro.20 14.05.020

(14) European Commission. Commission Regulation (EC) No 2073/2005 of 15 November 2005 on microbiological criteria for foodstuffs. [Internet]. [Place unknown]: European Commission; 2005 Nov 15 [cited 2016 Oct 20]. Available from: http://eur-lex.europa.eu/legalcontent/EN/ALL/?uri=CELEX\%3A32005 R2073

(15) Health Canada. Policy on Listeria monocytogenes in Ready-to-Eat Foods (2011). [Internet]. Ottawa: Health Canada; 2011 [cited 2016 Oct 20]. Available from: http://www.hc-sc.gc.ca/fnan/legislation/pol/policy_listeria_monocyt ogenes_2011-eng.php\#appa

(16) Government of British Columbia, Queen's Printer. Food Premises Regulation.

[Internet]. Victoria: Queen's Printer; 2016 [cited 2016 Oct 20]. Available from: http://www.bclaws.ca/EPLibraries/bclaws nnew/document/ID/freeside/11_210_99

(17) James SJ, Evans J, James C. A review of the performance of domestic refrigerators. J Food Eng [Internet]. 2008;87(1):2-10. Available from: http://linkinghub.elsevier.com/retrieve/pii/ S0260877407002063

(18) Garrido V, García-Jalón I, Vitas AI. Temperature distribution in Spanish domestic refrigerators and its effect on
Listeria monocytogenes growth in sliced ready-to-eat ham. Food Control [Internet]. Elsevier Ltd; 2010;21(6):896-901.

Available from:

http://dx.doi.org/10.1016/j.foodcont.2009. 12.007

(19) Huang J, Luo Y, Nou X. Growth of Salmonella enterica and Listeria monocytogenes on Fresh-Cut Cantaloupe under Different Temperature Abuse Scenarios. J Food Prot. 2015;78(6):112531.

(20) Feng K, Hu W, Jiang A, Xu Y, Sarengaowa, Li X, et al. Growth Potential of Listeria Monocytogenes and Staphylococcus Aureus on Fresh-Cut Tropical Fruits. J Food Sci. 2015;80(11):M2548-54.

(21) Giménez B, Dalgaard P. Modelling and predicting the simultaneous growth of Listeria monocytogenes and spoilage micro-organisms in cold-smoked salmon. J Appl Microbiol. 2004;96(1):96-109.

(22) SmartButton - Products - ACR Systems Data Loggers and Data Logging Solutions [Internet]. ACR Systems Inc. 2016 [cited 18 November 2016]. Available from: http://www.acrsystems.com/products/sma rtbutton/

(23) MacLeod M. Where to Place SmartButtons in Coolers (personal communication); British Columbia Institute of Technology; 2016.

(24) Wong D. How to Use AutoCAD (personal communication). Burnaby, B.C.; 2016.

(25) Beaufort A, Rudelle S, Gnanou-Besse N, Toquin M, Kerouanton A, Bergis $\mathrm{H}$ et al. Prevalence and growth of Listeria monocytogenes in naturally contaminated cold-smoked salmon. Letters in Applied Microbiology. 2007;44(4):406-411.

(26) Australia New Zealand Food Authority.

Evaluation of the Public Health Implications of Standard 1.6.1 Limits for Listeria Monocytogenes in Cold-Smoke Salmon. 2002 p. 5.

(27) McIntyre L, Shyng S, Barrios P. FSSP Growth Parameters. $655 \mathrm{~W}$ 12th Ave, Vancouver, BC; 2016.

(28) Implementation of the 2011 Health Canada Policy on Listeria monocytogenes 
in Ready-to-Eat Foods - Food - Canadian Food Inspection Agency [Internet].

Canadian Food Inspection Agency. 2014

[cited 18 November 2016]. Available

from:

http://www.inspection.gc.ca/food/fishand-seafood/product-inspection/fishlisteria/eng/1338572158747/13385726784

17 